\title{
Korelasi Berat Badan dan Umur Sapi terhadap Berat, Volume Cairan dan Konsentrasi Prostaglandin $\mathrm{F}_{2} \alpha$ pada Vesikula Seminalis
}

\author{
Correlation between Weight, Fluid Volume and Prostaglandin $F_{2} \alpha$ in \\ Seminal Vesicle of Cattle
}

\section{Naela Wanda Yusria Dalimunthe ${ }^{1}$, Agung Budiyanto², Erna Prawita Setyowati ${ }^{3}$, Agustina Dwi Wijayanti ${ }^{4}$,}

\author{
${ }^{1}$ Program Studi Kesehatan Hewan, Sekolah Vokasi, Universitas Gadjah Mada, Yogyakarta \\ Jl. Yacaranda Sekip Unit II, Yogyakarta 55281, Telp: +62 274 581124, \\ Email : d3keswan.sv.ugm.ac.id, Email: dalimunthe_naela@yahoo.com; naela.wanda@ugm.ac.id \\ ${ }^{2}$ Departemen Reproduksi dan Obstetri, Fakultas Kedokteran Hewan, Universitas Gadjah Mada, Yogyakarta \\ ${ }^{3}$ Fakultas Farmasi, Universitas Gadjah Mada, Yogyakarta Sekip Utara, Yogyakarta, 55281, \\ Telp: (0274)543120,Fax : (0274)543120,Email : farmasi@ugm.ac.id \\ ${ }^{4}$ Departemen Farmakologi, Fakultas Kedokteran Hewan, Universitas Gadjah Mada, Yogyakarta
}

\begin{abstract}
Seminal vesicles were collected from 60 heads of Bulls which butchered in slaughter house (RPH) Yogyakarta. The aims of this study are knowing the relationship between body weight, age, fluids volume and concentration of prostaglandin $\mathrm{F}_{2} \alpha\left(\mathrm{PGF}_{2} \alpha\right)$ in seminal vesicle of beef cattle. Those seminal vesicles were gathered from bulls which recorded its body weight and age then measured its seminal vesicles for weight, fluids volume and PGF2 $\alpha$ levels. The $\mathrm{PGF}_{2} \alpha$ level was measured by Enzyme-Linked Immunosorbent Assay. Statistical analysis was performed using one way - analysis of varian, regression and correlation with $\mathrm{P}<0.05$. Body weight of bulls showed positive correlation with the weight of seminal vesicle and its fluids volume. However, $\mathrm{PGF}_{2} \alpha$ levels were not correlated with the body weight of cattle. Weight of seminal vesicles also exhibited positive correlation with volume of vesicle fluids but no correlation with $\mathrm{PGF}_{2} \alpha$ levels. Based on the age of bulls, there were no correlation with the weight of seminal vesicles, seminal fluids volume and $\mathrm{PGF}_{2} \alpha$ levels. Those result indicated that the weight and fluids volume were affected by the body weight of bulls altough the $\mathrm{PGF}_{2} \alpha$ levels have a standard of development which seems affected by other factors such as concentration of androgen hormone.
\end{abstract}

Keywords : cattle, body weight, age, seminal vesicle, $\mathrm{PGF}_{2} \alpha$

\begin{abstract}
Abstrak
Vesikula seminalis dikoleksi dari 60 ekor sapi yang dipotong di Rumah Potong Hewan Yogyakarta. Tujuan dari penelitian ini adalah mengetahui hubungan antara berat badan, umur, volume cairan dan konsentrasi prostaglandin $\mathrm{F}_{2} \alpha\left(\mathrm{PGF}_{2} \alpha\right)$ dari vesikula seminalis sapi potong. Tingkat konsentrasi $\mathrm{PGF}_{2} \alpha$ diukur menggunakan Enzyme-Linked Immunosorbent Assay (ELISA) kit. Analisa statistik dilakukan menggunakan one way ANOVA, regresi dan korelasi dengan $\mathrm{P}<0.05$. Berat badan sapi menunjukkan korelasi positif terhadap berat vesikula seminalis dan volume cairan yang dihasilkan. Konsentrasi $\mathrm{PGF}_{2} \alpha$ tidak berkorelasi terhadap berat sapi. Berat vesikula seminalis memiliki korelasi positif terhadap volume vesikula seminalis tetapi tidak berkorelasi dengan konsentrasi $\mathrm{PGF}_{2} \alpha$. Berdasarkan pada umur sapi, parameter tersebut tidak berkorelasi dengan berat vesikula seminalis, volume cairan seminalis dan konsentrasi $\mathrm{PGF}_{2} \alpha$. Hasil tersebut mengindikasikan bahwa tingkat konsentrasi $\mathrm{PGF}_{2} \alpha$ memiliki standar perkembangan tersendiri yang kemungkinan dipengaruhi oleh faktor lain seperti konsentrasi hormon androgen.
\end{abstract}

Kata kunci: sapi potong, berat badan, umur, vesikula seminalis, $P G F_{2} \alpha$ 


\section{Pendahuluan}

Sapi jantan lokal merupakan aset yang harus dikembangkan semaksimal mungkin agar tepat guna dalam pengembangan tersebut diperlukan informasi yang akurat dari sapi yang secara fisik hidup di suatu wilayah dan dapat dikomparasikan dengan literatur global yang sudah ada (Rahman et al., 2010). Telah diketahui bahwa sapi jantan memiliki organ vesikula seminalis yang mampu mensekresikan berbagai jenis hormon seperti testosteron, estrogen, dan prostaglandin (Pemayun dkk, 2012; Shinde et al., 2014). Kelenjar vesikula seminalis pada sapi berbentuk kompak berlobus dan memiliki duktus sekretori/saluran pengeluaran intralobularis yang berbentuk sedikit melingkar dan bergabung menjadi duktus sekretori utama. Sel kolumner sekretoris memiliki sedikit droplet lemak dan glikogen sehingga mampu memberikan reaksi positif alkaline phosphatase. Sedangkan sel basal ditandai dengan adanya droplet lemak yang besar. Sekitar 50\% material lemak merupakan kolesterol dan turunannya, 25\% berupa trigliserid, dan 10\% phospholipid (Dellmann and Eurell, 1998). Produk sekresi vesikula seminalis bersifat gelatinous (likat), berwarna putih hingga putih kekuningan dan kaya akan fruktosa yang akan berfungsi sebagai sumber energi bagi spermatozoa yang diejakulasikan (Miki, 2007).

Vesikula seminalis adalah salah satu kelenjar asessoris pada saluran alat kelamin jantan. Ukuran dan anatominya sangat bervariasi di antara berbagai spesies hewan (JainudeenandHafez, 2000). Masing-masing dari vesikula terhubung dengan pelvis urethra di daerah vesika urinaria, yang artinya duktus ekskretorius terbuka melalui colliculis seminalis. Vesikula seminalis mensekresikan sejumlah cairan untuk menambah volume dan nutrisi bagi semen. Vesikula seminalis tidak berfungsi untuk menyimpan sperma (Miki, 2007). Hal ini berarti cairan semen merupakan medium yang mendukung kehidupan spermatozoa. Dua vesikula seminalis berkontribusi menghasilkan sekitar $60 \%$ dari volume air mani. Cairan dari vesikula seminalis memiliki konsistensi kental, kekuningan, dan basa yang disekresikan ke dalam saluran ampula. Cairan ini berisi lendir, gula fruktosa (yang menyediakan sebagian besar energi bagi sperma), enzim coagulating, asam askorbat, dan regulator local bernama prostaglandin (Jainudeen dan Hafez, 2000). Beberapa peneliti melaporkan bahwa kelenjar vesikula seminalis mensekresikan $\mathrm{PGF}_{2} \alpha$. Semen manusia mengandung sejumlah besar prostaglandin yang diproduksi dari kelenjar vesikula seminalis dan telah dibuktikan teridentifikasi dalam konsentrasi tinggi pada vasektomi (Gonzales, 2001). Glandula vesikula seminalis diketahui mensekresikan hormon prostaglandin $F_{2} \alpha$ tetapi belum banyak kajian mengenai konsentrasi $\mathrm{PGF}_{2} \alpha$ dari cairan yang dikoleksi langsung dari glandula tersebut. Informasi mengenai hormon $\mathrm{PGF}_{2} \alpha$ dari sapi lokal dan hubungannya dengan berat badan maupun umur juga belum banyak dilaporkan. Tujuan dari penelitian ini adalah untuk mengetahui morfologi glandula vesikula seminalis dari sapi jantan yang ada di Yogyakarta serta mengetahui hubungan antara berat dan umur sapi terhadap berat glandula vesikula seminalis, volume cairan yang dihasilkan dan konsentrasi $\mathrm{PGF}_{2} \alpha$.

\section{Materi dan Metode}

Dalam penelitian ini dipakai vesikula seminalis dari 60 ekor sapi jantan dengan berbagai 
macam bangsa sapi (28 ekor sapi PO, 7 ekor sapi Simental, 4 ekor sapi Limousin, 5 ekor sapi LimPO, 11 ekor sapi SimPO dan 5 ekor sapi Brahman Cross) yang dipotong di Rumah Potong Hewan (RPH) Yogyakarta. Dokumentasi sampel berdasarkan pada berat dan umur sapi. Proses pengambilan kelenjar vesikula seminalis dilakukan sesuai standar operasional prosedur pemotongan hewan besar yang berlaku di RPH.

\section{Pengambilan Cairan Vesikula Seminalis}

Proses penimbangan dan pengukuran dilakukan segera setelah vesikula seminalis sampai di laboratorium dengan menggunakan timbangan dan penggaris standar kemudian dilanjutkan dengan pengoleksian cairan vesikula seminalis. Cairan vesikula seminalis dikoleksi dengan cara masase yang dilakukan dengan mengurut vesikula dari ujung organ ke arah ductus secretorius segera di aspirasi menggunakan spuit $1 \mathrm{ml}$. Cairan yang diperoleh selanjutnya dimasukkan ke dalam vial dan disimpan pada temperatur $-4^{\circ} \mathrm{C}$ sampai saat digunakan.

\section{Analisis Hormon}

Pengukuran konsentrasi $\mathrm{PGF}_{2} \alpha$ dilakukan dengan menggunakan analisis hormon $\mathrm{PGF}_{2} \alpha$ dengan metode ELISA di laboratorium Fisiologi, Fakultas Kedokteran Hewan, Universitas Gadjah Mada. Sebanyak 30 sampel dipilih secara acak untuk mewakili semua bangsa sapi yang dipergunakan dan dikombinasikan dengan kit yang dipesan dari (Enzyme-Linked Immunosorbent Assay) ELISA kit (CEA749Ge) dengan metode Indirect ELISA (Competitive ELISA) dalam 96 well-plate untuk mengetahui konsentrasi $\mathrm{PGF}_{2} \alpha$.

\section{Analisis Data}

One way ANOVA, regresi dan korelasi digunakan untuk menganalisa data parameter yang terdistribusi normal dengan varians-nya. Angka kepercayaan yang dipergunakan adalah $\mathrm{P}<0.05$ untuk menyatakan data statistik yang signifikan dan metode Tukey's test digunakan untuk membandingkan data distribusi normal dan metode Dunn's digunakan apabila uji normal gagal dilakukan (Setyawan et al., 2015). Seluruh nilai rerata yang disampaikan berupa mean dan standar error of mean (mean \pm SEM).

\section{Hasil dan Pembahasan}

Rata rata berat sapi yang dipergunakan adalah $441.5 \pm 30.6 \mathrm{~kg}$ dengan rerata umur $2.3 \pm 0.2$ tahun. Berat kelenjar vesikula seminalis sebesar $85.9 \pm$ $13.4 \mathrm{~g}$ dengan volume cairan sebanyak $10.4 \pm 4.0$ $\mathrm{ml}$ dan konsentasi PGF2 $\alpha$ rata-rata $6.4 \pm 0.3 \mathrm{pg} / \mathrm{ml}$ seperti terlihat pada Tabel 1. Vesikula seminalis atau juga dikenal sebagai glandula vesikula merupakan kelenjar asesori hewan memiliki peran yang nyata dan penting dalam mengatur fungsi neuroendokrin dan berbagai perilaku reproduksi dan sosial dengan struktur berlobus terletak di dekat leher kandung kemih dan sisi lateral ampula (Jainudeen and Hafez, 2000). Panjang glandula vesikula seminalis menurut Hafez (2000) adalah $13 \mathrm{~cm}$ sedangkan Getty (1975) melaporkan bahwa panjang glandula tersebut adalah $10-12 \mathrm{~cm}$. Whittier (1993) menuliskan bahwa panjang glandula seminalis adalah $4-5$ inchi atau 10.2 - $12.7 \mathrm{~cm}$ dan Rahman et al. (2010) menyatakan panjang vesikula seminalis sebelah kanan dan kiri berurutan adalah $9.4 \mathrm{~cm}$ dan $8.6 \mathrm{~cm}$. Berdasarkan referensi tersebut di atas maka panjang glandula vesikula seminalis pada penelitian ini $(11.9 \pm 1.5 \mathrm{~cm})$ 
Tabel 1. Rerata data (mean $\pm S E M)$ dari seluruh sampel yang diperiksa $(\mathrm{n}=60)$.

\begin{tabular}{|c|c|c|c|c|c|c|}
\hline Berat Sapi (kg) & $\begin{array}{l}\text { Umur } \\
\text { (tahun) }\end{array}$ & $\begin{array}{c}\text { Berat } \\
\text { V. Seminalis } \\
\quad(\mathrm{g})\end{array}$ & $\begin{array}{c}\text { Volume } \\
\text { Cairan (ml) }\end{array}$ & $\begin{array}{c}\text { Panjang } \\
\text { Vesikula } \\
\text { Seminalis }(\mathrm{cm})\end{array}$ & $\begin{array}{c}\text { Lebar } \\
\text { Vesikula } \\
\text { Seminalis } \\
(\mathrm{cm})\end{array}$ & $\begin{array}{c}\text { Konsentrasi } \\
\mathrm{PGF}_{2} \alpha \\
(\mathrm{pg} / \mathrm{ml})\end{array}$ \\
\hline $441.5 \pm 30.6$ & $2.3 \pm 0.2$ & $85.9 \pm 13.4$ & $10.4 \pm 4.0$ & $11.9 \pm 1.5$ & $6.7 \pm 1.5$ & $6.4 \pm 0.3$ \\
\hline
\end{tabular}

Tabel 2. Distribusi berat dan volume cairan vesikula seminalis serta konsentrasi $\mathrm{PGF}_{2} \alpha$ dari beberapa kelompok berat sapi dengan kisaran umur antara 1-4 tahun.

\begin{tabular}{clcccc}
\hline $\begin{array}{c}\text { Kelompok } \\
\text { Berat }\end{array}$ & $\begin{array}{c}\text { Berat } \\
\text { V. Seminalis }(\mathrm{g})\end{array}$ & $\begin{array}{c}\text { Volume Cairan } \\
\text { V. Seminalis } \\
(\mathrm{ml})\end{array}$ & $\begin{array}{c}\text { Panjang } \\
\text { Vesikula } \\
\text { Seminalis }(\mathrm{cm})\end{array}$ & $\begin{array}{c}\text { Lebar } \\
\text { Vesikula } \\
\text { Seminalis } \\
(\mathrm{cm})\end{array}$ & $\begin{array}{c}\text { Konsentrasi } \\
\mathrm{PGF}_{2} \alpha \\
(\mathrm{pg} / \mathrm{ml})\end{array}$ \\
\hline $200-380 \mathrm{~kg}$ & $64.1 \pm 6.3^{\mathrm{a}}$ & $5.2 \pm 0.9^{\mathrm{a}}$ & $9.4 \pm 0.5$ & $6.1 \pm 0.1^{\mathrm{a}}$ & $5.6 \pm 0.4$ \\
$381-570 \mathrm{~kg}$ & $91.5 \pm 8.7^{\mathrm{ab}}$ & $10.7 \pm 1.7^{\mathrm{b}}$ & $13.1 \pm 2.1$ & $6.6 \pm 0.2^{\mathrm{a}}$ & $6.2 \pm 0.6$ \\
$571-750 \mathrm{~kg}$ & $120.6 \pm 13.6^{\mathrm{b}}$ & $20.5 \pm 4.4^{\mathrm{c}}$ & $12.5 \pm 0.4$ & $7.8 \pm 0.4^{\mathrm{b}}$ & $8.1 \pm 1.9$ \\
\hline
\end{tabular}

${ }^{a, b}$ superscript yang berbeda dalam kolom menunjukkan perbedaan yang nyata $(\mathrm{P}<0.05), \mathrm{n}=60$.

tergolong normal. Berat glandula vesikula seminalis yang diperoleh dalam penelitian ini $(85.9 \pm 13.4 \mathrm{~g})$ menunjukkan angka yang sedikit lebih tinggi dari laporan yang diberikan oleh Hafez (2000) maupun Rahman et al. (2010) yaitu $75 \mathrm{~g}$ dan $38.4 \mathrm{~g}$.

\section{Pengaruh berat badan sapi}

Pada Tabel 2 terlihat bahwa berat vesikula seminalis pada kelompok berat 200 - $380 \mathrm{~kg}(64.1$ $\pm 6.3 \mathrm{~g})$ lebih rendah secara signifikan $(\mathrm{P}<0.05)$ dibandingkan dengan kelompok berat badan 571 - $750 \mathrm{~kg}$ (120.6 $\pm 13.6 \mathrm{~g})$. Volume cairan vesikula seminalis memiliki perbedaan yang nyata diantara ke 3 kelompok berat yang dipergunakan yaitu kelompok berat badan $200-380 \mathrm{~kg}$ memiliki volume cairan (5.2 $\pm 0.9 \mathrm{ml})$ yang lebih rendah dari pada kelompok berat badan $381-570 \mathrm{~kg}(10.7 \pm 1.7 \mathrm{ml})$ sedangkan kelompok berat badan 571 - $750 \mathrm{~kg}$ memiliki volume cairan tertinggi $(20.5 \pm 4.4 \mathrm{ml})$ dibandingkan 2 kelompok lainnya. Sedangkan konsentrasi $\mathrm{PGF}_{2} \alpha$ tidak menunjukkan adanya perbedaan diantara ke 3 kelompok berat badan tersebut. Perbedaan yang signifikan tersebut dilanjutkan dengan pemeriksaan besarnya pengaruh berat badan sapi terhadap variabel yang ada menggunakan analisa regresi dan korelasi seperti pada Gambar. Hasil perhitungan menunjukkan bahwa berat sapi memiliki korelasi terhadap berat vesikula seminalis dengan $\mathrm{r}^{2}$ sebesar 0.24 dan angka kepercayaan $\mathrm{P}=0.0002$. Sedangkan korelasi antara berat sapi terhadap volume cairan diperoleh $\mathrm{r}^{2}$ sebesar 0.32 dan angka kepercayaan $\mathrm{P}<0.0001$.

Berat badan sapi memiliki korelasi yang signifikan terhadap berat vesikula seminalis dan demikian juga dengan volume cairan, panjang dan lebar vesikula seminalis yang menunjukkan korelasi positif seperti pada Tabel 4. Hal tersebut sesuai dengan pendapat (Jainudeen and Hafez, 2000) yang mengatakan bahwa ukuran glandula vesikula seminalis mengikuti pertumbuhan tubuh dan cenderung bervariasi pada setiap spesies. 


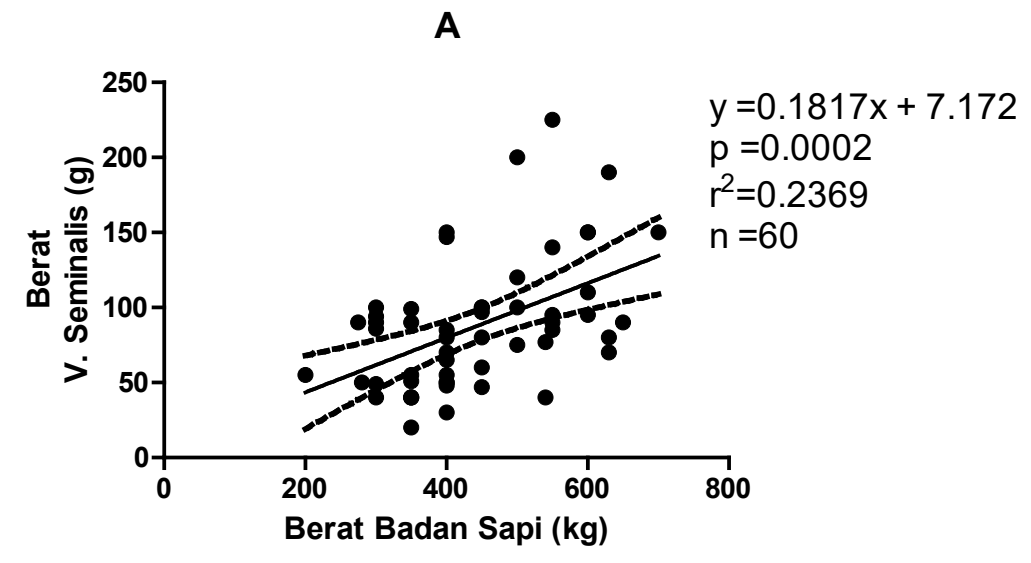

B

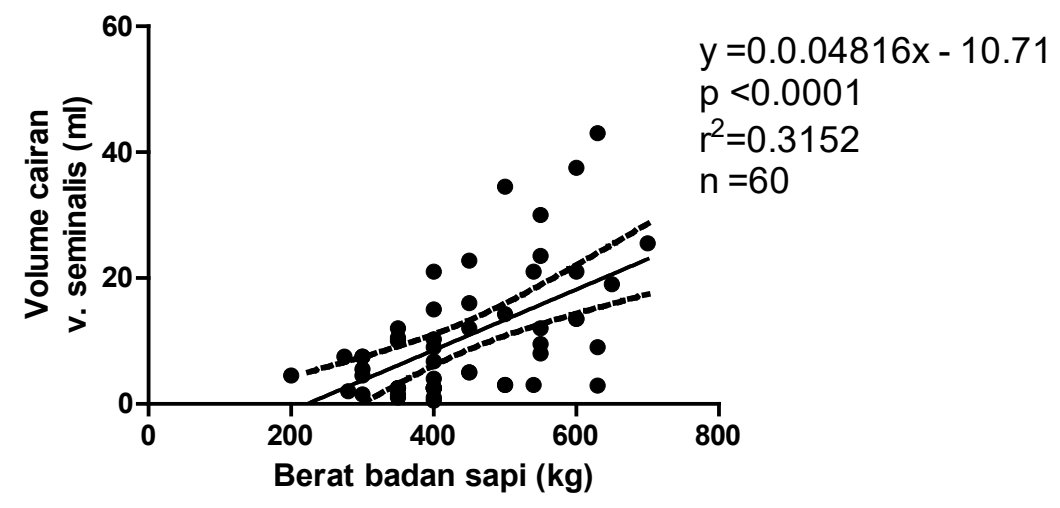

Gambar. Hasil analisa regresi dan korelasi antara berat adan sapi terhadap berat vesikula seminalis (A) dan volume cairan vesikula seminalis (B).

Tabel 3. Pengaruh umur sapi jantan terhadap berat dan volume cairan vesikula seminalis serta konsentrasi $\mathrm{PGF}_{2} \alpha$.

\begin{tabular}{cccccc}
\hline Kelompok Umur & $\begin{array}{c}\text { Berat } \\
\text { V. Seminalis }(\mathrm{g})\end{array}$ & $\begin{array}{c}\text { Volume Cairan } \\
\text { V. Seminalis }(\mathrm{ml})\end{array}$ & $\begin{array}{c}\text { Panjang } \\
\text { Vesikula } \\
\text { Seminalis }(\mathrm{cm})\end{array}$ & $\begin{array}{c}\text { Lebar Vesikula } \\
\text { Seminalis }(\mathrm{cm})\end{array}$ & $\begin{array}{c}\text { Konsentrasi } \\
\text { PGF }_{2} \alpha \\
(\mathrm{pg} / \mathrm{ml})\end{array}$ \\
\hline $1.0-1.9$ tahun & $71.8 \pm 10.1$ & $7.6 \pm 2.1$ & $15.3 \pm 5.9$ & $6.1 \pm 0.1^{\mathrm{a}}$ & $9.4 \pm 2.9$ \\
$2.0-2.9$ tahun & $95.2 \pm 10.6$ & $10.9 \pm 2.1$ & $11.9 \pm 0.3$ & $6.6 \pm 0.2^{\mathrm{b}}$ & $6.5 \pm 0.8$ \\
$3.0-3.9$ tahun & $84.3 \pm 8.4$ & $11.7 \pm 2.5$ & $10.3 \pm 0.5$ & $7.8 \pm 0.4^{\mathrm{b}}$ & $5.6 \pm 0.3$ \\
\hline
\end{tabular}

${ }^{\mathrm{a}, \mathrm{b}}$ superscript yang berbeda dalam kolom menunjukkan perbedaan yang nyata $(\mathrm{P}<0.05), \mathrm{n}=60$.

\section{Pengaruh umur sapi}

Umur sapi tidak menunjukkan adanya pengaruh terhadap berat, volume cairan, panjang dan lebar vesikula seminalis serta konsentrasi $\mathrm{PGF}_{2} \alpha$ seperti terlihat pada Tabel 3 berikut. Kelompok umur 1.0-1.9 tahun memiliki berat vesikula seminalis
(71.8 $\pm 10.1 \mathrm{~g})$ yang tidak berbeda dengan kelompok umur 2.0-2.9 tahun (95.2 $\pm 10.6 \mathrm{~g})$ dan 3.0-3.9 tahun $(84.3 \pm 8.4 \mathrm{~g})$. Demikian juga dengan volume cairan dan konsentrasi $\mathrm{PGF}_{2} \alpha$ yang tidak menunjukkan perbedaan signifikan dari ke 3 pengelompokan umur yang ditentukan. 
Tabel 4. Korelasi antara berat dan umur sapi terhadap berat, volume cairan, ukuran vesikula seminalis dan konsentrasi $\mathrm{PGF}_{2} \alpha$.

\begin{tabular}{llll}
\hline Regresi dan korelasi & Nilai $\mathrm{R}^{2}$ & Nilai P & Signifikansi \\
\hline Berat sapi vs Berat vesikula seminalis & 0.2369 & 0.0002 & Signifikan \\
Berat sapi vs Volume cairan vesikula seminalis & 0.3152 & $<0.0001$ & Signifikan \\
Berat sapi vs Panjang vesikula seminalis & 0.1495 & 0.0032 & Signifikan \\
Berat sapi vs Lebar vesikula seminalis & 0.1370 & 0.0050 & Signifikan \\
Berat sapi vs Konsentrasi PGF $_{2} \alpha$ & 0.0018 & 0.8414 & Tidak \\
Umur sapi vs Berat vesikula seminalis & 0.0137 & 0.4092 & Tidak \\
Umur sapi vs Volume cairan vesikula seminalis & 0.0386 & 0.1673 & Tidak \\
Umur sapi vs Panjang vesikula seminalis & 0.0092 & 0.4909 & Tidak \\
Umur sapi vs Lebar vesikula seminalis & 0.0154 & 0.3718 & Tidak \\
Umur sapi vs Konsentrasi PGF $_{2} \alpha$ & 0.0020 & 0.8435 & Tidak \\
\hline
\end{tabular}

Pada penelitian ini diketahui bahwa umur sapi tidak menunjukkan adanya pengaruh terhadap berat dan volume cairan vesikula seminalis serta konsentrasi $\mathrm{PGF}_{2} \alpha$. Hasil analisa korelasi yang dilakukan pada faktor umur terhadap parameter lain juga tidak ditemukan adanya korelasi yang signifikan seperti yang dapat dilihat di Tabel 4. Hal ini sekilas tampak berbeda dengan laporan Jainudeen dan Hafez (2000) bahwa faktor umur memiliki pengaruh terhadap ukuran dan aktivitas vesikula seminalis pada beberapa hewan, (Rahman et al., 2010) juga menyatakan seiring dengan bertambahnya umur seekor sapi, ukuran vesikula seminalis akan bertambah dan telah diketahui bahwa terdapat korelasi positif antara umur hewan dengan ukuran vesikula seminalis terutama antara umur 2 tahun dibanding umur 4 tahun. Namun Rahman et al. (2010) menambahkan bahwa ukuran dan berat glandula vesikula seminalis pada sapi umur 2-3 tahun tidak berbeda nyata. Berdasarkan rentang umur pada laporan tersebut maka umur sapi yang dipergunakan pada penelitian ini dapat dikategorikan pada kelompok sapi muda sehingga pengaruh umur tidak signifikan berbeda.

Konsentrasi $\mathrm{PGF}_{2} \alpha$ tidak terpengaruh dengan umur sapi maupun berat badan sapi. Hal ini lebih disebabkan karena sapi yang dipotong di RPH didominasi oleh sapi potong yang kemungkinan besar tidak pernah dimanfaatkan sebagai pejantan sehingga aktifitas hormon androgennya sebatas kadar yang diperlukan untuk pertumbuhan dan pemeliharaan sistem reproduksi jantan saja. Kemungkinan tersebut didasarkan pada beberapa laporan sebelumnya bahwa pertumbuhan dan aktifitas sekresi pada glandula vesikula seminalis dipengaruhi oleh tingkat konsentrasi hormon androgen yang ditentukan oleh aktifitas seksual dan libidonya (Gonzales, 2001).

Kajian faktor berat dan umur sapi terhadap berat dan volume cairan vesikula seminalis serta konsentrasi $\mathrm{PGF}_{2} \alpha$ diperoleh beberapa hubungan yang telah diterangkan sebelumnya. Hal yang menarik adalah bahwa konsentrasi $\mathrm{PGF}_{2} \alpha$ diketahui tidak memiliki perbedaan diatara kelompok faktor yang telah ditentukan dan tidak menunjukkan adanya korelasi dengan faktor-faktor tersebut. Hal tersebut menunjukkan bahwa konsentrasi $\mathrm{PGF}_{2} \alpha$ dalam cairan vesikula seminalis dipengaruhi oleh faktor lain yang lebih spesifik. Almenara et al. (2000) melaporkan bahwa beberapa peneliti yang mencoba mengetahui hubungan konsentrasi $\mathrm{PGF}_{2} \alpha$ dalam plasma semen dengan faktor luar diperoleh bahwa 
pemberian injeksi testosteron atau hormon androgen lain mampu meningkatkan aktifitas sekresi sekaligus meningkatkan berat organ vesikula seminalis. Sedangkan Masoumi et al. (2011) melaporkan bahwa injeksi $\mathrm{PGF}_{2} \alpha$ pada sapi dengan libido rendah dapat meningkatkan kualitas ejakulat, konsentrasi testosteron dan libido. Hubungan yang saling mempengaruhi ini menunjukkan bahwa konsentrasi $\mathrm{PGF}_{2} \alpha$ ditentukan oleh tingkat konsentrasi hormon androgen yang menentukan aktifitas seksual dan libidonya seperti yang dikemukakan oleh Gonzales (2001). Dengan kata lain, konsentrasi $\mathrm{PGF}_{2} \alpha$ sebanding dengan konsentrasi hormon androgen salah satunya testosteron dan keseluruhan sistem endokrin tersebut berkembang bersama dengan proses pubertas hewan (Hafez, 2000).

Hormon $\mathrm{PGF}_{2} \alpha$ yang terkandung di dalam cairan vesikula seminalis dapat diukur dengan menggunakan metode ELISA yang artinya semakin membuka kesempatan untuk menggunakan kelenjar vesikula seminalis dari limbah pemotongan sapi sebagai sumber penghasil hormon $\mathrm{PGF}_{2} \alpha$ dengan metode ekstraksi seperti yang telah dilaporkan Pemayun dkk. (2012). Volume cairan vesikula yang tinggi dapat diperoleh dari sapi dengan berat badan yang tinggi meskipun konsentrasi $\mathrm{PGF}_{2} \alpha$ tidak dapat dipastikan tinggi namun dimungkinan untuk mendapatkan jumlah total hormon $\mathrm{PGF}_{2} \alpha$ yang lebih banyak.

\section{Kesimpulan}

Kesimpulan yang dapat diperoleh dari penelitian ini adalah konsentrasi hormon $\mathrm{PGF}_{2} \alpha$ dapat terukur di dalam cairan vesikula seminalis dengan kadar tertentu dan tidak ditemukan adanya pengaruh dari berat hidup maupun umur sapi. Berat badan sapi memiliki korelasi positif terhadap berat, volume cairan, panjang dan lebar vesikula seminalis tetapi tidak ditemukan adanya pengaruh terhadap konsentrasi $\mathrm{PGF}_{2} \alpha$. Umur sapi antara 1.0-3.9 tahun tidak memiliki pengaruh terhadap berat dan ukuran vesikula maupun volume cairan vesikula seminalis.

\section{Daftar Pustaka}

Almenara, A, Escalante, G, Gazzo, E, Gonzales, GF. 2000. Transillumination to evaluate spermatogenesis: Effect of testosterone enanthate in adult male rats. Arch Androl; 46: 21-8.

Dellmann, H.D and J. Eurell, 1998. Veterinary Histology. Fifth Edition. Williams and Wilkins Publishing. Philadelphia. USA. pp: 238-243.

Getty, R. 1975. Sisson and Grossman's The Anatomy of the Domesticated Animals. Fifth Edition. Philadelphia: Saunders. pp: 942-946.

Gonzales, GF. 2001. Function of seminal vesicles and their role on male fertility. Asian J Androl 3:251-258.

Hafez, ESE. 2000. Anatomy of Male Reproduction. "In Reproduction in Farm Animals". Hafez (7 th ed.). Lippincott William \& Wilkins. A Wolter Kluwer Company. pp: 8-9.

Jainudeen, MR, dan Hafez, ESE. 2000. Gestation, prenatal, physiology, and parturition. In:Reproduction in Farm Animals, Edisi ke 7. Lippincott Williams \& Wilkins, Philadelphia. pp: $140-141$.

Masoumi, R, Towhidi, A, Javaremi, AN, Nabisadeh, $H$, Zhandi, M. 2011. Influence of PGF2 $\alpha$ on semen quality and libido in Holstein bulls. Turk. J. Vet. Anim. Sci.; 35(1): 1-6.

Miki, K. 2007. Energy Metabolism and Sperm Function. Soc Reprod Fertil Suppl.65:309-25.

Pemayun, TGO, Mahaputra, L, Ismudiono, Soetjipto. 2012. Kadar Prostaglandin F2 alfa pada produk 
biakan sel Monolayer vesikula seminalis dan endometrium sapi Bali dengan penambahan hipotaurin, Jurnal Kedokteran Hewan, Vol. 6, No. 1.

Rahman, MS, Islam, MS, Rahman, MT, Parvez, NH, Rahman, MM. 2010. Morphometric analysis of vesicular glands of indigenous bull. Int. J. Sustain. Crop Prod. 5(1):11-14.

Setyawan, EMN, Kim, MJ, Oh, HJ, Kim, GA, Jo, YK, Lee, SH, Choi, YB, Lee, BC. 2015. Maintaining canine sperm function and osmolyte content with multistep freezing protocol and different cryoprotective agents. Cryobiology 71: 344-349.

Shinde, S, Mahmood, S, Singh, G, and Verma, MR. 2014. Association between the seminal vesicle weight and certain steroids in buffaloes (Bubalus bubalis), Veterinary World 7(1): 2125.

Whittier, JC. 1993. Reproductive Anatomy and Physiology of the Bull, University of Missouri Extension. University Extension Agricultural Publications. Columbia. http://extension. missouri.edu/p/G2016. 